\title{
Determinants of Service Quality in the Trucking Industry
}

\author{
Jeffrey Kennedy \\ Palm Beach Atlantic University
}

\begin{abstract}
Trucking firms play a fundamental role in connecting supply chain elements in many U.S. market channels and firms of all kinds depend on trucks to pick up and deliver goods. Even though many products move just about all the way by ship, train, or airplane, almost everything is carried by a truck at some point during the delivery process (Statistics, 2007). Because of this dependence on trucks, it is critical that managers in trucking firms continually strive to meet and exceed customer and shipper customer service requirements and expectations (Meixell, 2008). The purpose of this research was to examine whether cargo handling by truck drivers had an effect on a company's service quality perceptions as perceived by the recipients of commercial cargo. The SERVQUAL instrument was used to measure the gap between truck drivers' determinants of service quality as perceived by the recipient of the goods from these truck drivers. The findings from the study suggest it becomes necessary for managers to train these truck drivers in more than merely following a route or delivering goods. They need real marketing customer service skills and this should be factored into their training program.
\end{abstract}

\section{INTRODUCTION}

Marketing emerged as a separate discipline originally concerned with the process of moving goods from producer to consumer. "This goods-centered manufacturing-based model of economic exchange developed during the Industrial Revolution, and since then marketing has broadened its perspective to include the exchange of more than manufactured goods" (Vargo, 2004). The sub-discipline of services marketing and its importance to scholars and practitioners emerged to address this broadened perspective in the 1970s and 1980s. Individual industries mirrored the growing recognition that America had become a service economy. Driven by supply and demand, an integrative field focused on the marketing of intangible products (Berry \& Parasuraman, 1993).

In today's service economy, the emerging dominant logic is focused on the interaction of the producer and the consumer and other supply and value network partners as they co-create value through collaborative processes (Sweeney, 2007). This new logic is being referred to as the service-dominant logic with research suggesting we do not just buy goods and services, but relationships, brands experiences, dreams and many other interacting phenomena. Also recognized is the co-creation of value between customers and suppliers and within this paradigm a genuine customer orientation (Gummesson, 2008). Further evidence of the value of providing value to customers through exceptional service to customers is documented by Rust who concluded that firms that primarily focus on customer service will do better than firms that primarily focus on cost reduction (Rust, Moorman, \& Dickson, 2002). 
The attitude and actions of contact employees can affect customers' perceptions of the service. Other studies have emphasized the influence a service employee has on a customer's' perceptions of service quality. Results indicate that employees' positive and negative behaviors are highly correlated to the customers' overall satisfaction (Kattara, 2008). Moreover, research indicates many service firms fail in delivering service quality to their customers because their employees deliver inferior value to the end user (Scheepers, 2006). The attitude and actions of contact employees can affect customer's perceptions of the service. Because of the importance of the service encounter, service firms must find ways to effectively manage their customer-contact employees to help ensure their attitude is conducive to the delivery of quality service (Elmadag, 2008)).

Firms remain challenged in delivering high quality service to its customers, largely because understanding the process consumers draw on to purchase and evaluate services is complex. Nonetheless service quality remains a key area of interest to practitioners, managers, and researchers who recognize the impact it has on business performance, customer satisfaction, purchase intentions and financial outcomes (Seth, Deshmukh, \& Vrat, 2005; Greising, 1994; Bienstock, Mentzer, \& Bird, 1997). Although many empirical studies examining general quality management practices have been performed over time, industry-specific studies on quality management practices and factors that influence their success in the shipping industry are rather few (Cheng \& Choy, 2007, p. 234).

\section{LITERATURE REVIEW}

Logistics impacts our lives and the economy in a very significant way. For example, in 2007 there were 9.6 million people working in transportation-related jobs across all sectors of the U. S. economy, excluding the self-employed. Table 1.1 shows the breakdown of employees in transportation and materials handling related jobs by industry. Nearly $67 \%$ of those working in transportation and materials handling related jobs are employed in the transportation and warehousing sector, manufacturing sector or the wholesale and retail industries. Data supplied by the US Department of labor show that in 2017 approximately one out of every 9 people working in the U.S. was employed in a transportation and material moving-related job. The number of employed in trucking-related jobs (excluding the selfemployed grew from 7.8 million in 1994 to 8.6 million in 2003, an increase of 9.1\%. From 2003 to 2007 the number increased to 9.6 million and increase of $10.4 \%$ U.S. Department of Labor, 2009). An interesting and significant factor concerning this research is truck drivers and driver sales workers hold 45 percent of all jobs in the industry.

TABLE 1.1

EMPLOYMENT IN FOR-HIRE TRANSPORTATION ESTABLISHMENTS PRIMARILY SERVING FREIGHT: 2000, 2010, AND 2015-2016 ${ }^{1}$ (IN THOUSANDS)

\begin{tabular}{|l|r|r|r|r|}
\hline & $(\mathbf{R}) \mathbf{2 0 0 0}$ & $(\mathbf{R}) \mathbf{2 0 1 0}$ & $(\mathbf{R}) \mathbf{2 0 1 5}$ & $\mathbf{2 0 1 6}$ \\
\hline Total U.S. labor force $^{2}$ & 132,033 & $\mathbf{1 3 0 , 3 5 3}$ & $\mathbf{1 4 1 , 8 1 3}$ & $\mathbf{1 4 4 , 3 0 6}$ \\
\hline Transportation and warehousing & $\mathbf{4 , 4 1 2}$ & $\mathbf{4 , 1 9 2}$ & $\mathbf{4 , 8 6 9}$ & $\mathbf{4 , 9 8 7}$ \\
\hline Rail transportation & 232 & 216 & 241 & 215 \\
\hline Water transportation $^{\prime}$ & 56 & 62 & 66 & 66 \\
\hline Truck transportation $^{3}$ & 1,406 & 1,251 & 1,453 & 1,454 \\
\hline Air Transportation & 614 & 458 & 458 & 476 \\
\hline Pipeline transportation $^{3}$ & 46 & 42 & 50 & 49 \\
\hline Support activities for transportation $^{4}$ & 537 & 543 & 652 & 660 \\
\hline Couriers and messengers $^{4}$ & 606 & 528 & 611 & 639 \\
\hline Warehousing and storage & 515 & 633 & 828 & 915 \\
\hline
\end{tabular}

KEY: $\mathrm{R}=$ revised 
NOTES: These data include workers employed in transportation industries but not necessarily in a transportation occupation, such as a lawyer working for a trucking company. Moreover, these data exclude workers in transportation occupations employed by non-transportation industries, such as a truck driver employed by a retail company.

SOURCE: U.S. Department of Labor, Bureau of Labor Statistics, Current Employment Statistics survey, available at https://www.bts.dot.gov/content/employment-hire-transportation-establishments-primarily-serving-freight-20002010-and-2015

Corporations and researchers also have become increasingly aware of the strategic role logistics services plan in a firm's overall success (Bienstock, Mentzer, Bird, \& Murphy, 1997). Anecdotal evidence from firms such as Dell Computer Corporation, Nabisco, and Federal Express suggest that logistics excellence has a significant impact on revenue and profitability (Mentzer, Flint, \& Hult, 2001 (Vansickle, 2002). "We feel 3PLs have improved in performance and in service offerings," noted Victor Guzman, Director of Supply Chain and Logistics with Honeywell International Inc. "They serve a specific purpose and outsourcing allows us to avoid significant capital investment in non-core activities" (Richardson, 2005, p.17).

Despite its growing importance in corporate strategy and the global economy, the logistics discipline does not have as rich a heritage of theory development and empirical research as older and more established disciplines such as anthropology, philosophy, psychology, and sociology (Stock, 1997). In fact, much of logistics literature and research has been considered managerial in nature and lacking a rigorous orientation toward theory development, testing, and application (Mentzer, Bienstock, \& Kahn, 1995).

Competition among transportation companies has dramatically increased in recent years Reasons contributing to additional competition include deregulation of the industry, growing demands among shippers for better levels of service, and the relatively recent trend in the creation of third party logistics carriers. As common carriers compete more in each others' territories, more trucking firms are offering "higher quality service offerings to customers" (Kirkeby, 2008, p. 4). For reader clarity, a "carrier" or "common carrier" is defined by the U. S. Army Quartermaster Center and School as follows: "A for-hire carrier that holds itself out to serve the general public at reasonable rates and without discrimination (Bhardwaj \& Jain, 2007). In this study, carriers or common carriers will be limited to commercial trucking companies which transport goods between vendors and shippers and defined as follows: "One who ships goods for transportation. A for-hire carrier that holds itself out to serve the general public at reasonable rates and without discrimination" In this study, shippers prepare goods for shipment and carriers deliver the cargo via commercial truck to the end user.

Firms no longer view logistics as simply an area for cost improvements, but perceive logistics as a key source of competitive advantage within a firm's total market efforts ( $\mathrm{Ha}, \mathrm{Li}, \& \mathrm{Ng}, 2003$ ). Logistics service competence can be leveraged to create customer and market share by improving service performance, (Ha et al., 2003), increasing market share, (Daugherty, Stank, \& Ellinger, 1998), enabling mass customization (Bradley, Gooley, \& Cooke, 1998), creating effective customer-based systems (Closs, 2005), effecting customer satisfaction, (Dresner \& Kefung, 1995), providing a differentiation competitive advantage, (Rodrigues, Bowersox, \& Calantone, 2003), and segmenting customers (Gilmour, 1994).

Additionally, firms in a competitive industry are always under pressure to develop comparative advantages in resources that will give them an edge in some market segment or segments (Hunt, 1983). Providing the right level of service delivery to the right the customer in the right market segment may serve as a comparative advantage for firms delivering cargo door-to-door. (Sheetal \& Verma, 2004)

It is documented that the mishandling of cattle and livestock in transit has forced the launch of a quality assurance program by the National Pork Board in Des Moines IA. This program was launched because truckers were not handling animals completely to the satisfaction of the industry. According to 
Mr. David Meisinger, the Pork Board's Trucker Quality Assurance coordinator, mishandling of cargo by truck drivers' costs the industry approximately $\$ 59$ million in lost revenue per year (Vansickle, 2002).

The significance of this study and the role truck drivers' play in delivering service quality to end users is determined in part by the convergence of many economic factors. These factors include a firm's ongoing effort to remain competitive by delivering high quality service to its customers in a competitive global environment. Providing excellent quality service can be a competitive advantage (Porter, 1985).

Another significant reason for this study is that trucking operated in a regulated industry until 1980. Government regulation impacts competition in general and the operating performance of trucking firms. Included is the significant impact deregulation of the industry in 1980 has had. To ensure their survival firms are now forced to add a range of customer-oriented services to complement trucking delivery services. This is evidenced by the phenomenal growth of $3^{\text {rd }}$ party logistics providers. These providers offer value added services to firms engaged in delivering cargo throughout the supply chain.

Also there is growing evidence of the impact front line service employees have on overall customer satisfaction and relationship quality. "Organizations must develop information systems that enable frontline employees to build relationships effectively and to coordinate delivery of benefits to individual customers" (Mandrodt \& Davis, 1992, p. 3).

Finally, service firms must adapt to the current services dominant logic to compete. Although there is little empirical research, practitioners and researchers agree that drivers play a significant role in the transportation industry. Supply chain partners all converge, and operational outcomes, relational outcomes, and overall business performance are affected by efficient pick-up and delivery of customer cargo. (Zacharia, Nix, \& Lusch, 2009). This researcher posits there are many variables that impact and may influence the commercial truck driver's efficiency and effectiveness in a driver's delivery of superior service quality to the end user. In short, the data support a need for firms to continue to look into ways of providing better service to its customers.

Firms must become accustomed to the increased competition from global competitors as well as increased competition from local firms. In addition, the deregulation of the industry in 1980 predestined firms to adjust their service offerings to upgrade their service delivery in an ever increasing business environment in a non regulated environment. Furthermore, more demanding customers require firms to add value to its service offering, a fact demonstrated by the explosive growth of $3^{\text {rd }}$ party logistics companies during the last two decades. In addition, there is little empirical research in this area of logistics (Ashenbaum, Maltz, \& Rabinovich, 2005). Finally, current research is being done in the area of front line service employees and their impact on service quality. Research shows that customers make evaluative judgments of the service quality delivered by these front line staff members. Consequently, the behaviors and attitudes of front-line staff that provide services are crucial for the positive evaluation of services by customer (Bienstock, DeMoranville, \& Smith, 2003). In the end firms must provide better ways of delivering excellent service. Their very survival depends on it. (Walker, Johnson, \& Leonard, 2006)

\section{Disconfirmation Paradigm}

The disconfirmation paradigm asserts that customers compare perceived product performance to perceived expectations. The disconfirmation paradigm is the widely accepted view of the process by which customers develop feelings of satisfaction or dissatisfaction. (Cadotte, Woodruff, \& Jenkins, 1987; Sheetal \& Verma, 2004). Expectations are the reference points customers have before experiencing the service whereas perceptions reflect their subjective experience assessments of the service that they have actually received. The expected service consists of what a customer believes should or will happen. For example, a customer expects a much higher level of service when traveling first class as opposed to traveling coach. Because customer satisfaction is critical to firm competitiveness, organizations will strive to close or narrow this gap, i.e., between what is expected and what is received to satisfy their customers, and to build long-term relationships with them (Ching-Chow, 2003).

Churchill and Surprenant state, "Disconfirmation arises from discrepancies between prior expectations and actual performance. It is presumably the magnitude of the disconfirmation effect that 
generates satisfaction and dissatisfaction" (p. 492). The disconfirmation-expectation model assumes that a customer's degree of satisfaction is an outcome of a four step process (Anderson, Rungfusanatham, Schroeder, \& Devaraj, 1995). In a perfect world, expectations and perceptions would be identical: customers would receive what they thought they would and should receive. In practice these concepts are often, even usually, separated by some distance. Broadly speaking, it is the goal of services marketing to bridge this distance, or closes the gap between customer expectations and customer perceptions of service quality (Muslim \& Zaidi, 2008).

Addressing and closing them is challenging because services are performances and most of the time it is people who render these performances (Berry, Zeithaml, \& Parasuraman, 1990). For this reason, many service firm managers recognize the importance of service employees in communicating with and satisfying their customers (Bebko \& Sciulli, 2009). Parasuraman, Zeithaml \& Berry, (1985) found from their interviews that a set of key discrepancies or gaps exist regarding executive perception of service quality and the tasks associated with service delivery to customers. These gaps can be major hurdles in attempting to deliver a service which the customer would perceive as being of high quality. (Chowdurry, 2009)

The gaps model, (Parasuraman, Zeithaml, \& Berry, 1985) further suggests that four other gaps- the provider gaps- need to be closed. These gaps occur within the organization providing the service (hence the term the provider gaps) and include the following:

Gap 1: Not knowing what customers expect.

Gap 2: Not selecting the right service design and standards.

Gap 3: Not delivering to service design and standards.

Gap 4: Not matching performance to promises.

Provider gap 1 is the difference between customer expectations of service and company understanding of those expectations. A primary cause in many firms for not meeting customers' expectations is that the firm lacks accurate understanding of exactly what those expectations are (Chowdhury, 2009). There are many reasons why managers may not be aware of what customers expect: they may not interact directly with customers, they may be unwilling to ask about expectations, or they may be unprepared to address them (Warden, Tsung-Chi, Chi-Tsun, \& Chi-Hsun, 2003). Further, because there are few clearly defined and tangible cues for services, this gap may be considerably larger than it is in firms that produce tangible goods (Gronroos, 1982; Webster, 1992).

A number of factors have been shown to be responsible for provider gap 1. First, because marketing research is a key vehicle for understanding consumer expectations and perceptions of services, the size of gap 1 depends greatly on the amount of marketing research conducted (Zeithaml, Berry, \& Parsuraman, 1988). A second factor is a lack of upward communication. Frontline employees often know a great deal about customers (Schneider, 1985), but management may not be in contact with frontline employees and may not understand what they know. A third factor is a lack of company strategies to retain customers and strengthen relationships with them (Gwinner, Gremler, \& Bitner, 1998). A fourth factor is inadequate attention to service recovery-understanding why people (Lafferty \& Colgate, 2001)strategies for dealing with inevitable service failures (Walker, Johnson, \& Leonard, 2006).

A recurring theme in service companies is the difficulty experienced in translating customer expectations into service quality specifications that employees can understand and execute (Niranjan \& Metri, 2008). Provider gap 2 is the difference between company understanding of customer expectations and development of customer-driven service designs and standards. Customer-driven standards differ from the conventional performance standards in that they are based on pivotal customer requirements that are visible to and measured by customers (Zeithaml \& Bitner, 2003). (Narasimhan, 2004)

Provider gap 3 is the discrepancy (Zeithaml V. B., 1996) (Zeithaml V. \&., 2003) between development of customer-driven service standards and actual service performance by company employees (Narasimhan, 2004). Even when guidelines exist for performing services well and treating customers correctly, high-quality service performance is not a certainty. Standards must be backed by appropriate resources (people, systems and technology) and also must be enforced to be effective-that is, employees must be measured and compensated on the basis of performance along those standards 
(Zeithaml, Berry, \& Parsuraman, 1988). When the level of service delivery falls short of the standards, it falls short of what customers expect as well. Narrowing gap 3-by ensuring that all resources needed to achieve the standards are in place-reduces the customer gap.

Provider gap 4 illustrates the difference between service delivery and the service provider's external communications (Lafferty \& Colgate, 2001). Promises made by a service company through its media advertising, sales force, and other communications may potentially raise customer expectations, the standards against which customers assess service quality (Duffy \& Ketchand, 1998). The discrepancy between a (Ahmet, Subbash, Mehves, \& Selim, 2005)_actual and promised service therefore has an adverse effect on the customer gap. Broken promises can occur for many reasons: overpromising in advertising or personal selling, inadequate coordination between operations and marketing, and differences in policies and procedures across service outlets (Ahmet, Subbash, Mehves, \& Selim, 2005). (Asubonteng, McCleary, \& Swan, 1996)Because service advertising promises what people do, and because what people do cannot be controlled like machines that produce physical goods can be controlled, this type of communication involves functions other than the marketing department. This kind of interaction between contact people and customers must be examined (Potocan, 2008). (Brooks \& Ritchie, 2005)

\section{Service Quality}

Researchers have proposed and evaluated both alternative service quality models and also instruments for measuring service quality for the past two decades (Seth, Deshmukh, \& Vrat, 2005; Asubonteng, McCleary, \& Swan, 1996). Service quality models help management recognize quality concerns and aide in planning quality improvement programs that help to improve efficiency, profitability and in particular firm performance. The most important aim of these models is to allow management to be aware of and improve the quality of the business and its service offering (Seth, Deshmukh, \& Vrat, 2005). Among these models, SERVQUAL (Parasuraman, 1985; 1988) is the most prominent and the most widely used (Parikh, 2005).

Little has been written about the trucking industry despite the growing importance of logistics in corporate strategy and the global economy (Brooks \& Ritchie, 2005). The logistics discipline does not have as rich a heritage of theory development and empirical research as older and more established disciplines such as anthropology, philosophy, psychology, and sociology (Stock, 1997). In fact, much logistics literature and research has been considered largely anecdotal in nature and lacking a rigorous orientation toward theory development, testing, and application (Mentzer, Bienstock, \& Kahn, 1995). (Crosby \& LeMay)

One of the biggest challenges logistics providers face as they provide service from the supplier to the customer is to assess the value and impact these activities have on overall business performance. In fact, definitive empirical results that link improvements to logistics performance to overall firm performance have been difficult to achieve. Although progress has been made, Professor Donald Bowersox, logistics professor at Michigan State University, noted during the Logistics Management Annual Conference in Toronto in 1999 that establishing a link between functional logistics performance and overall firm performance in the logistics industry is the equivalent to the medical field's dilemma of finding a cure for cancer. In other words, there is much empirical research to be done (Bowersox, Closs, \& Stank, 2000). This author hopes to add to the body of knowledge and posits that truck drivers play a central role in a company's assessment of service quality as these drivers deliver cargo to the end user. Research already indicates that the attitude and actions of contact employees can affect customer's perceptions of the service. Other studies have emphasized the influence a service employee has on a customer's perceptions of service quality. Other research indicates employees' positive and negative behaviors are highly correlated to the customers' overall satisfaction (Kattara, Weheba, \& El-said, 2008). Moreover, research indicates many service firms fail in delivering service quality to their customers because their employees deliver inferior value to the end user (Scheepers, 2006).

A large body of transportation quality research addressed the measurement or determination of customer service elements. Many of these papers used survey or case study data as the basis for their 
findings. Chow \& Poist, (1984) surveyed shippers to determine the transportation service-quality factors measured. These factors most often cited related to rates, claims, transit time, equipment and operations. Hopkins, (Rhea \& Shrock, 1987) Strasser, Willie, \& Foster, (1993) surveyed both shippers and carriers to determine service-quality gaps between two groups. Using nineteen service-quality items taken from SERVQUAL, the researchers found that carriers generally knew the level of service-quality expected by shippers, but were not providing it. The authors suggested future research was needed to identify the causes for these internal failures.

Other researchers offered theoretical discussions of transportation of logistics service-quality for the transportation industry and the elements that should be used to measure it Rhea \& Shrock, (1987) presented a framework for measuring physical distribution effectiveness. Rogers, Daugherty, \& Stank, (Rogers, 1993) took the ten key service-quality determinants from Parasuraman, Zeithaml, and Berry and suggested potential logistics-related measures for each determinant. The authors argued that customer perception surveys used by logistics providers should be designed around these factors.

Using the SERVQUAL instrument, Hopkins, Strasser, Willie, \& Foster's, (1993) study was an attempt to analyze service quality within the industry transportation industry and to determine potential areas of improvement within the carrier shipper relationship. Crosby \& LeMay, (1998) addressed three methods by which trucking managers may discover customer requirements because trucking managers must effectively elicit these quality dimensions and the value customers place on each one. The methods used are SERVQUAL, direct questioning, and policy capturing techniques. The authors note (Hopkins, 1993) (Hartline, 1996) (Ladhari, 2008) (Parasuraman, 1988) (Ghobadian, 1994) (Parikh, 2005) each method has its strengths and limitations in helping managers in the trucking industry gather information that helps define and satisfy customer requirements. The SERVQUAL instrument permits the use of exploratory factor analysis to discover what service elements are valued by customers. The weakness in this instrument is that it does not force the respondents to choose a single factor.

Personnel contact quality refers to the customer orientation of the supplier's logistics contact people. Specifically, customers care about whether customer service personnel are knowledgeable, empathize with their situation, and help them resolve their problems (Bitner, Boons, \& Mohr, 1994) (Gronroos, 1984). Hartline and Ferrell 1996; Parasuraman, Zeithaml, and Berry 1985). Parasuraman, Zeithaml, and Berry (1985) argue that in most service encounters, quality perceptions are formed during the service delivery.

Similarly, Hartline and Ferrell suggest that service quality perceptions are tied more to the service process, which involves personnel contact, than to the resulting service outcome. As such, personnel contact quality is an important aspect of the employee-customer interface (Hartline and Ferrell 1996; Hartline, Maxham, and McKee 2000; Mentzer, Flint, Hult (2001).

The SERVQUAL instrument has been designed to be applicable across a broad spectrum of services. As such, it provides a basic skeleton through an expectations / perceptions format, encompassing statements for each of the five service quality dimensions. SERVQUAL is most valuable when it is used periodically to track service trends (Ladhari, 2008). It can help a wide range of service organizations in assessing consumer expectations about the perceptions of service quality. It can also help in pinpointing areas requiring managerial attention and action needed to improve service quality (Ladhari, 2008).

SERVQUAL contains 22 pairs of Likert-type items. One half of these items are intended to measure consumers' expected levels of service for a particular service industry (expectations). The other 22 matching items are intended to measure the perceived level of service provided by a particular organization (perceptions). The two components of SERVQUAL (e.g., expectations and perceptions) are designed to measure consumer "desired level" of service from a sector and the "existing level" of service from a particular provider. Service quality is then measured by calculating the difference between corresponding items (in other words, perceptions minus expectations (Parasuraman, Zeithaml, \& Berry, 1988).

One of the major problems using this five-dimensional structure is applying it to services. Most services are intangible. Services are performances rather than objects which cannot be seen felt or tasted (Ghobadian, 1994). Therefore, services are perishable and cannot be stored in one time period for 
consumption at a later date. This means that, unlike manufactured goods, it is not possible to have a final check (Ghobadian, 1994). The service provider needs to get the service right the first time, every time.

Although SERVQUAL remains the most widely used measure of service quality to date, it has received criticism (Parikh 2005). This criticism has focused on a number of aspects including the value and conceptualization of the expectations side of the instrument. Cronin and Taylor, 1992 Also, authors have had concerns with expectation scores in terms of variance restriction (Babakus and Boller, 1992; Brown \& Churchill, 1993).

As a result of the literature examination, the following five hypotheses have been identified.

H1- Truck driver tangibles are related to service quality expectations.

H01- Truck driver tangibles are not related to service quality expectations.

$\mathrm{H} 2$ - Truck driver reliability is related to service quality expectations. (Babakas, 1992)

H02- Truck driver reliability is not related to service quality expectations

H3- Truck driver responsiveness is related to service quality expectations.

H03- Truck driver responsiveness is not related to service quality expectations.

H4- Truck driver assurance is related to service quality expectations.

H04- Truck driver assurance is not related to service quality expectations.

H5- Truck driver empathy is related to service quality expectations.

H05- Truck driver empathy is not related to service quality expectations.

\section{METHODOLOGY}

An adapted version of the SERVQUAL instrument was used to collect the data and was designed to measure the gap between truck drivers' determinants of service quality as perceived by the recipient of the goods from these truck drivers. The data used in this study were derived from a personal interview survey conducted with local firms in various industry groups located in the South Florida area including Miami-Dade and Broward Counties. An adapted version of the SERVQUAL instrument was used to collect the data and was designed to measure the gap between truck drivers' determinants of service quality as perceived by the recipient of the goods from these truck drivers. The recipient of goods consisted of warehouse managers and loading dock supervisors from various industry groups. The receiving firms also ranged in size, with a diversified ownership structure. The sampling was aimed at reaching those businesses whose success is determined in part by the quality of service their firm's truck drivers provide to diverse industry groups.

Unlike the methodology used by Parasuraman, Zeithaml, \& Berry, (1988), this study employed a twopart questionnaire with separate expectation and perception sections, where the expectation statements were grouped together and formed the first half of the instrument and corresponding perception statements formed the second half. The present study elicited consumer expectations for an excellent truck driver delivering service quality encounters to recipients of cargo with only one list of statements and two portions of measurement.

Respondents were instructed to indicate the level of service that should be offered by an excellent commercial firm delivering cargo via truck and to express their perceptions about the quality of the delivery experience.

\section{Data Collection}

The next phase of the research consisted of contacting these firms by telephone to determine if truck driving and cargo delivery were considered vital contributors to the firm's success. To do this the researcher contacted the individual in the company whose primary job functions included shipping and receiving of cargo. Initial contact was by telephone. The person in charge of this receiving cargo had a number of different titles. The job title included but not was limited to warehouse manager, shipping manager, and receiving manager. 
The data collection process consisted of two parts. The first part consisted of telephone interview with the warehouse manager. The purpose of this initial telephone interview was to determine if overall truck driver performance was considered a determinant of their firms' success. If the warehouse manager agreed that that receiving cargo was an important determinant of firm success the SERVQUAL questionnaire was administered electronically.

\section{Prescreening}

Survey participants were logistics professionals selected because of their intimate involvement with the shipping and receiving of cargo for their firms. Telephone calls to a pilot sample demonstrated that these individuals carry many different titles depending upon firm size, location, and industry. Some of the titles include: Logistics Manager, Dispatcher, and Warehouse Manager. These managers' perceptions of truck driver determinants of service quality were tested using a SERVQUAL instrument.

The next phase of the research consisted of contacting these firms by telephone to determine if truck driving and cargo delivery were considered vital contributors to the firm's success. To do this the researcher contacted the individual in the company whose primary job functions included shipping and receiving of cargo. Initial contact was by telephone. The person in charge of receiving cargo had a number of different titles. The job title included but not was limited to warehouse manager, shipping manager, and receiving manager.

The data collection process consisted of two parts. The first part consisted of telephone call to the firm to get in contact with and telephone interview the warehouse manager. The purpose of this initial telephone interview was to determine if overall truck driver performance was considered a determinant of their firms' success. If the warehouse manager agreed that that receiving cargo was an important determinant of firm success the SERVQUAL questionnaire was emailed to them electronically.

The responses to the questionnaire statements relating to the service features were measured using a seven-point scale where "7" represented strong agreement and " 1 " represented disagreement.

Expectations and perceptions were also measured on a 7-point scale. Gaps are measured by finding the difference between these responses, resulting in a possible range from -6 , indicating a massive shortfall to +6 , indicating a great degree of exceeding expectations. SERVQUAL scores (perceptions minus expectations) can be used to assess a given firm's quality for each service feature. It is needed to measure the expectations level of a customer for a specific feature. The firm's performance can then be judged on the service given to the customer. Service quality along each of the five dimensions can be found by averaging the different scores on items making up the dimension. It can also provide an overall measure of service quality in the form of an average score across all five dimensions.

Frequency distributions were run on the adapted SERVQUAL instrument's 22 questions. The scores awarded to each item were tallied and central tendency statistics were created (e.g., mean, median, mode, high and low scores, and standard deviation

Demographic data regarding business size, type of industry and business ownership were also tallied and analyzed for. Frequency of each value was counted and percentages, established. Demographic variables (type of industry, business ownership, and business size) were considered, for the purposes of this study.

Other experts doing similar studies have used this technique as well as results from this study will be easily compared to previous work. In many statistical studies the goal is to establish a relationship, expressed via an equation for predicting typical values of one variable given the value of another variable. This task fits well with the nature of regression analysis. Lastly, the nature of the research question is to compare relationships between independent driver determinants with a recipient's perception of service quality, the dependent variable. 


\section{Stepwise Regression}

Additionally, Linear Regression will be used to establish a relationship for predicting typical values of one variable given the value of another variable. In addition to predicting the outcome variable for a new sample of data, regression analysis serves other purposes: to assess how well the dependent variable can be explained by knowing the value of the independent variable (or a set of independent variables) and to identify which subset from many measures is most effective for estimating the dependent variable (SPSS, 1999).

Step-wise regression is appropriate to search for the "best" model by bringing into the regression equation the dependent variables one by one. Each variable in the model is tested as a new variable enters. The dependent variable is the overall service quality perception. The independent variables are the five service quality dimensions: Tangibles (Tan), Reliability (Rel), Responsiveness (Res), Assurance (Ass), and Empathy (Emp) (Hair, Anderson, Tatham, \& Black, 2005).

Management's challenge is to improve service quality. And firms utilize different research approaches with customer groups to ensure that they are hearing what customers expect (Berry \& Parasuraman, 1997). The interactions between the provider who delivers the service and the recipient of the service delivery influence the relationship. What happens during these interactions significantly impacts perceived service quality, the relationship and the retention of (Meixell, 2008)customers? The challenge for service firms is to identify the characteristics, behaviors, and/or processes that connote quality and to satisfy the customer's need, influence the perceived value and contribute to customer retention. Empirical evidence is lacking on what logistics service quality is to customers and whether it has different meanings for separate customer segments. This researcher posits there are many variables to be considered while examining the interaction between the delivery person and the end user and these variables will differ along customer segments.

\section{RESULTS}

As discussed, this research is to use an adapted version of the SERVQUAL instrument to measure the gap between truck drivers' determinants of service quality as perceived by the recipient of the goods from these truck drivers in a business-to-business service environment. Multiple regression was used to test the hypotheses. In this study an adapted version of the SERVQUAL instrument was used to measure the gap between truck drivers' determinants of service quality as perceived by the recipient of the goods from these truck drivers in a business-to-business service environment. Multiple regression was used to test the hypotheses.

\section{Survey Respondents}

The sample selected was a convenience sample chosen from a group of firms engaged in the movement of cargo whose dependence on timely delivery was a vital element to the firms' success. Truck drivers are in the unique position of affecting services as promised; one of the leading pitfall areas of logistics service quality. Due to the unique impact of a driver on services rendered, firms interested in strengthening the quality commitments of zero defects, continuous improvement, and sustained performance (i.e. the necessary basic quality commitments,) must focus attention to this critical area (Zeithaml, 2000). The central objective of the research is to examine truck driver determinants of service quality as perceived by warehouse and loading dock personnel, therefore it was necessary to choose industry groups most likely to transport and receive cargo via professional truck drivers. The research was to be conducted in South Florida, and specifically in Broward County. Consequently, the researcher chose the following industry group from the data base of ReferenceUSA for the sample: "Wholesale Distributors" (NAICS 50-51). This reduction of the strata resulted in a sample frame size consisting of 6,373 .

By randomly selecting every $6^{\text {th }}$ business firm an initial sample size of 1062 potential survey respondents wer (Zeithaml V. )e to be called on by telephone. From that sample, 114 usable responses 
were included in the results. The questionnaire was found reliable with an aggregate cronbach alpha of .77.

TABLE 4-1

RESPONDEDNT PROFILE/RESPONSE DATA

\begin{tabular}{|l|l|l|l|l|}
\hline & $\begin{array}{c}\text { Variables } \\
\text { (Number of Employees) }\end{array}$ & Frequency & Percent & $\begin{array}{c}\text { Cumulative } \\
\text { Percent }\end{array}$ \\
\hline Valid & LT50 & 37 & 32.5 & 32.5 \\
\cline { 2 - 5 } & $50-250$ & 33 & 28.9 & 61.4 \\
\hline & $250-999$ & 6 & 5.3 & 66.7 \\
\hline \multirow{2}{*}{} & 1000 Plus & 38 & 33.3 & 100.0 \\
\cline { 2 - 5 } & Total & 114 & 100.0 & 100.0 \\
\hline
\end{tabular}

\section{Data Analysis}

Twenty-two items representing five factors (Tangibles, Reliability, Responsiveness, Empathy and Assurance) were analyzed for their impact in this study and their effect on the dependent variable of overall service quality perceptions were assessed.

\section{Mean Gap Total}

The following mean gap table is categorized into four sections for clarity. The first table below (Gap Table 4-16), represents respondents' mean gap score totals ranging between -3.50 to -2.00 . This gap score range indicates recipients were extremely dissatisfied with the level of service they received compared to their expectation level. The second table (Gap Table 4-17) represents respondents' gap score totals between -1.99 and -1.50 . This gap score range indicates respondents were moderately displeased with the overall level of service they received from providers compared to their expectation level. The third table (Gap Table 4-18) represents respondents' mean gap score totals between-.1.49 to 0.00. Respondents falling in this range indicate that survey respondents were either slightly unsatisfied with their level of service received or received the exact level of service they expected. The fourth table (Gap Table 4-19) represents respondent gap score totals between +.049 and +1.00 . Gap scores in this range show that these participants received a level of service quality that exceeded their level of expectations.

\section{Gap Scores}

\begin{tabular}{|l|l|l|l|}
\hline VARIABLE & EXPECTATION & PERCEPTION & GAP SCORE \\
\hline Tangibles & 4.9978 & 4.9890 & -0.0088 \\
\hline Reliability & 5.7754 & 4.7053 & -1.0701 \\
\hline Responsiveness & 5.7982 & 4.7053 & -1.0929 \\
\hline Assurance & 5.7982 & 4.5877 & -1.2105 \\
\hline Empathy & 5.3333 & 4.1930 & -1.1403 \\
\hline
\end{tabular}

The five independent variables generated five hypotheses. Each factor is discussed and then the results of the multiple regression analysis for each factor are presented.

\section{Hypotheses Testing}

Multiple regression analysis was utilized to analyze the hypotheses. A level of significance less than .05 indicates the variable is a significant predictor of the dependent variable. If the significance level is between .05 and .10 then the relationship is considered marginal.

H1a: The expectation of truck driver tangibles is related to service quality. 
TABLE 4-24

COEFFICIENTS ${ }^{\text {a }}$ FOR TANGIBLES

\begin{tabular}{|l|l|l|l|l|l|l|}
\hline \multirow{2}{*}{ Model } & $\begin{array}{l}\text { Unstandardized } \\
\text { Coefficients }\end{array}$ & $\begin{array}{l}\text { Standardized } \\
\text { Coefficients }\end{array}$ & $\mathrm{t}$ & \multicolumn{3}{|c|}{} \\
\cline { 2 - 5 } & $\mathrm{B}$ & Std. Error & Beta & Sig. & \\
\hline 1 & (Constant) & -.151 & .060 & -.195 & -2.543 & .012 \\
\cline { 2 - 6 } & $\begin{array}{l}\text { Mean tangible } \\
\text { expectations }\end{array}$ & & & & & \\
\hline
\end{tabular}

a. Dependent Variable: mean gap total

The multiple regression analysis for truck driver tangibles identified a significance level of .012 .

H2: The expectation of truck driver reliability is related to service quality.

TABLE 4- 25

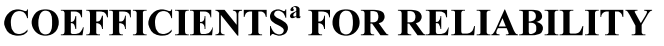

\begin{tabular}{|c|c|c|c|c|c|c|}
\hline \multirow[b]{2}{*}{ Model } & $\begin{array}{l}\text { Unstandardized } \\
\text { Coefficients } \\
\end{array}$ & $\begin{array}{l}\text { Standardized } \\
\text { Coefficients }\end{array}$ & $\mathrm{t}$ & \multirow[b]{2}{*}{ Sig. } & & \\
\hline & B & Std. Error & Beta & & & \\
\hline & $\begin{array}{l}\text { mean reliability } \\
\text { expectations }\end{array}$ & -.102 & .059 &.-128 &.-1.731 & .086 \\
\hline
\end{tabular}

a. Dependent Variable: mean gap total

The multiple regression analysis of truck driver reliability identified a significance level of.086.

H3: The expectation of truck driver responsiveness is related to service quality.

TABLE 4- 26

COEFFICIENTS ${ }^{\text {a }}$ FOR RESPONSIVENESS

\begin{tabular}{|c|c|c|c|c|c|c|}
\hline \multirow[b]{2}{*}{ Model } & $\begin{array}{l}\text { Unstandardized } \\
\text { Coefficients }\end{array}$ & $\begin{array}{l}\text { Standardized } \\
\text { Coefficients }\end{array}$ & $\mathrm{t}$ & \multirow[b]{2}{*}{ Sig. } & & \\
\hline & $\mathrm{B}$ & Std. Error & Beta & & & \\
\hline & $\begin{array}{l}\text { mean responsiveness } \\
\text { expectations }\end{array}$ & -.218 & .045 & -.263 & -4.812 & .00 \\
\hline
\end{tabular}

a. a. Dependent Variable: mean gap total

The multiple regression analysis for truck driver responsiveness identified a significance level of.000.

H4: The expectation of truck driver assurance is related to service quality expectations. 
TABLE 4- 27

COEFFICIENTS ${ }^{\text {a }}$ FOR ASSURANCE

\begin{tabular}{|l|l|l|l|l|l|l|}
\hline \multirow{2}{*}{ Model } & $\begin{array}{l}\text { Unstandardized } \\
\text { Coefficients }\end{array}$ & $\begin{array}{l}\text { Standardized } \\
\text { Coefficients }\end{array}$ & \multicolumn{2}{|c|}{$\mathrm{t}$} & \multicolumn{3}{|c|}{ Sig. } \\
\cline { 2 - 5 } & $\mathrm{B}$ & Std. Error & Beta & Sig. \\
\hline \multirow{3}{*}{$\begin{array}{l}\text { mean assurance } \\
\text { expectations }\end{array}$} & -.266 & .051 & -.308 & -5.205 & .00 \\
\cline { 2 - 7 } & & & & & \\
\hline
\end{tabular}

a. a.

Dependent Variable: mean gap total

The multiple regression analysis for truck driver assurance identified a significance level of .000

H5: The expectation of truck driver empathy is related to service quality.

TABLE 4- 28

COEFFICIENTS ${ }^{\text {a }}$ FOR EMPATHY

\begin{tabular}{|c|c|c|c|c|c|c|}
\hline \multirow[b]{2}{*}{ Model } & $\begin{array}{l}\text { Unstandardized } \\
\text { Coefficients }\end{array}$ & $\begin{array}{l}\text { Standardized } \\
\text { Coefficients } \\
\end{array}$ & $\mathrm{t}$ & \multirow[b]{2}{*}{ Sig. } & & \\
\hline & B & Std. Error & Beta & & & \\
\hline & $\begin{array}{l}\text { mean empathy } \\
\text { expectations }\end{array}$ & -.343 & .055 & -.381 & -6.266 & .00 \\
\hline
\end{tabular}

a. Dependent Variable: mean gap total

The multiple regression analysis for truck driver empathy identified a significance level of .000.

\section{CONCLUSION}

This chapter presented the result of the data analysis. It includes descriptive statistics, estimates of scale reliability as well as hypothesis testing. Tables 4-24 to 4-28 provide a summary of the hypotheses testing results. The study failed to accept the null for hypotheses 2 . However, it accepted the null for hypotheses 1, 3 4, and 5. Chapter V discusses the results and statistical implications drawn from Chapter IV makes recommendations and provides direction for future research.

The study identified that four factors; reliability, responsiveness, assurance and empathy are significant in a warehouse manager's evaluation of a firm's service quality delivery of goods to their workplace.

The results of the study indicate that one factor; tangibles are significant in a warehouse manager's evaluation of a firm's service quality delivery of goods to their workplace. Reliability, responsiveness, assurance and empathy were not significant. Table 5-1 presents each of the factors and the SQ question that comprised the factor. 


\section{TABLE 5-1 \\ SUMMARY OF HYPOTHESES TESTING}

\begin{tabular}{|c|c|}
\hline Significant & Not significant \\
\hline Tangibles (.012) & Reliability (.086) \\
\hline $\begin{array}{l}\text { - product transport company should have } \\
\text { new vehicles }\end{array}$ & $\begin{array}{l}\text { promises to do something by a certain } \\
\text { time, it should do so. }\end{array}$ \\
\hline $\begin{array}{l}\text { product transport company's trucks } \\
\text { should be attractive. }\end{array}$ & $\begin{array}{l}\text { truck driver should be sympathetic and } \\
\text { reassuring }\end{array}$ \\
\hline $\begin{array}{l}\text { - drivers should be well dressed and appear } \\
\text { neat at all times. }\end{array}$ & $\begin{array}{l}\text { - drivers should arrive at their destination } \\
\text { at the time the company promised. }\end{array}$ \\
\hline \multirow[t]{2}{*}{ Significant } & Not significant \\
\hline & $\begin{array}{l}\text { drivers should keep their records } \\
\text { accurately }\end{array}$ \\
\hline \multicolumn{2}{|l|}{ Responsiveness (.000) } \\
\hline $\begin{array}{l}\text { should not be expected to tell customers } \\
\text { exactly when goods will be collected or } \\
\text { delivered }\end{array}$ & \\
\hline $\begin{array}{l}\text { should expect prompt services from } \\
\text { product transport companies }\end{array}$ & \\
\hline $\begin{array}{l}\text { drivers should always be willing to help } \\
\text { customers. }\end{array}$ & \\
\hline $\begin{array}{l}\text { - company is too busy to respond to } \\
\text { customer requests promptly }\end{array}$ & \\
\hline \multicolumn{2}{|l|}{ Assurance (.000) } \\
\hline - customers should be able to trust drivers. & \\
\hline $\begin{array}{l}\text { - Customers should be able to feel safe in } \\
\text { their transactions with the drivers }\end{array}$ & \\
\hline - Truck drivers should be polite & \\
\hline $\begin{array}{l}\text { Drivers should get adequate support from } \\
\text { their product transport companies to do } \\
\text { their jobs well. }\end{array}$ & \\
\hline \multicolumn{2}{|l|}{ Empathy (.000) } \\
\hline $\begin{array}{l}\text { Drivers cannot be expected to give } \\
\text { customers individual attention }\end{array}$ & \\
\hline $\begin{array}{l}\text { - Drivers cannot be expected to give } \\
\text { customers their personal attention }\end{array}$ & \\
\hline $\begin{array}{l}\text { It is unrealistic to expect drivers to know } \\
\text { what the customers' needs are }\end{array}$ & \\
\hline $\begin{array}{l}\text { Customers expect product transport } \\
\text { companies to have their customers' best } \\
\text { interest at heart }\end{array}$ & \\
\hline $\begin{array}{l}\text { - Companies are expected to have } \\
\text { convenient operating hours for all } \\
\text { customers. }\end{array}$ & \\
\hline
\end{tabular}

Tangibles, Responsiveness, Assurance, and Empathy were the strongest predictors of service quality and statistically significant, while Reliability was not statistically significant. 


\section{Practitioner Implications}

Closing the gap between customer-driven service standards in the transportation business and actual service performance by company employees will remain challenging. Even when procedures and guidelines exist for performing services well and treating customers correctly, high quality service performance is not guaranteed. Standards must be reinforced by appropriate company resources (people, systems, and technology) and also must be enforced to be successful. It is suggested that employees be measured and compensated on the basis of performance along those standards. As a result, even when standards accurately reflect customers' expectations, if the company fails to provide support for them by facilitating, supporting and requiring their attainment the standards do no good. When the level of truck driver service-delivery performance falls short of the standards, fails to achieve what customers expect as well. Narrowing this gap expectations and perceptions ensures that all the resources needed to achieve the standards are in place and reduces the customer gap.

The increase of $3^{\text {rd }}$ party logistics company's providing delivery services for host firm and replacing company employed drivers has led to drivers not clearly understanding their role in the delivery process. Drivers sometimes feel caught up in the middle between customers and company management and feel helpless. Drivers are often compensated in terms of the number of deliveries made in a workday and feel obligated to make deliveries in the most efficient way. This can cause drivers to be impatient with a strong desire to leave the premises as quickly as possible. In addition, paying truck drivers' low wages has forced management to hire the wrong or unqualified employees or even temporary help. Statistics show that driver turnover rates can exceed $100 \%$. Even though these drivers may not be the most qualified employees to perform the job adequately, management is forced to use these drivers because cargo is often perishable and trucks must leave the loading dock on time. The opportunity cost of leaving a truck in the loading dock is perceived as far greater than having an untrained driver making deliveries.

\section{LIMITATIONS OF THE STUDY}

As mentioned above, getting warehouse personal to fill out the survey twice was difficult. Warehouse personnel were sometimes confused about the questions and often needed explanations. Many of the respondents were not formally educated and extra care was needed to explain the purpose of the study. For others they had never before been asked to participate in a study and so this was a novel experience for them. Also, Florida does not have strong unions and these drivers tend to receive low wages and are perceived as unskilled labor. The sample size was low due to the difficulty in reaching the respondents. Also the population was limited to one local county.

\section{ENDNOTES}

1. Annual average across 12 months.

2. Excludes farm employment.

3. Data for air transportation includes passenger and freight transportation employment.

4. Industries in the support activities for transportation subsector provide services to transportation carrier establishments or to the general public. This subsector includes a wide array of establishments, including air traffic control services, marine cargo handling, and motor vehicle towing.

\section{REFERENCES}

Ahmet, K., Subbash, L., Mehves, T., \& Selim, Z. (2005). A Paradox of Service Quality in Turkey: The Seemingly Contradictory relative Importance of Tangible and Intangible Determinants of Service Quality. European Business Review, 17(1), 5-20.

Anderson, J. R. A path analytic model of a theory of quality management underlying the Deming management method: Preliminary empirical findings. Decision Sciences, 26 (5), 637-658. 
Ashenbaum, B. M. (2005). Studies of trends in third-party logistics usage: What can we conclude? Transportation Journal, 44(3), 39-50.

Asubonteng, P., McCleary, K., \& Swan, J. (1996). SERVQUAL Revisited; A Critical Review of Service Quality. Journal of Services Marketing, 10(6), 62-71.

Babakas, E. \&. (1992). An empirical assessment of the SERVQUAL scale. Journal of Business Research, 24(3).

Bebko, C. \&. The 'Spillover Effect" of percieved quality of employees on predictions of provider service quality. . Journal of Academy of Business, 14(2), 1-7.

Berry, L. (1997). Listenting to the customer: The concept of service quality information system. Sloan Management Review, 38(12), 65-72.

Berry, L. (1990). Five Imperatives for improving service quality. Sloan Management Review, 31(4), 2938.

Berry, L. Z. (1990). Five imperatives for improving service quality. Sloan Management Review, 3(14), 29-38.

Bhardwaj, M., \& Jain, V. K. (2007). Glossary of Purchasing and Supply Chain Management. New Delhi, India: Excel Books.

Bienstock, C. C. (2003). Organizational citizenship behavior and service quality. The Journal of Services Marketing, 17(4/5), 357-378.

Bienstock, C. M. (1997). Measuring physical distribution service quality. Academy of Marketing Science Journal, 25(1), 31-44.

Bienstock, C. M. (1997). Measuring physical distribution service quality. 25(1), 31-44.

Bitner, M., Boons, B., \& Mohr, L. (1994). Critical Service Encounters: The Employee's Viewpoint. Journal of Marketing, 58(4), 95-106.

Bowersox, D. C. (2000). Ten mega-trends that will revolutionize supply chain logistics. Journal of Business Logistics, 21(2), 1-15.

Bradley, P. G. (1998). Failure to meet logistics requirements can be costly. Logistics Management and Distribution Report, 37(10), 42-43.

Brooks, M., \& Ritchie, P. (2005). Trucking Mergers and Acquisitions in Canada and the U.S. since NAFTA. Transportation Journal, 44(3), 23-38.

Brown, T. C. (1993). Research note: Improving the measurement of service quality. Journal of Retailing, 69(1), 127-139.

Cadotte, E. R. (1987). Expectations and norms in models of consumer satisfaction. Journal of Marketing Research, 24(3).

Cantelon, P. \&. (1996). The roadway story. Rockville, MD: Montrose Press.

Cheng, T. C. Measuring success factors of quality managment in the shipping industry. Maritime Economics \& Logistics, 9(3), 234-253.

Ching-Chow, Y. (2003). Establishing an application of the integrated model of service quality management. Managing Service Quality, 13(4), 310-324.

Chow, G. \&. (1984). The measurement of quality of service and the transportation purchase decision. Logistics and Transportation Review, 20(1), 25-33.

Chowdurry, M. (2009). Customer expectations and management perceptions in healthcare services of Bangladesh: An overview. Journal of Service Research, 8(2).

Churchill, G. (1979). A paradigm for developing better measures of marketing constructs. Journal of Marketing Research, 19(000004), 14-27.

Churchill, G. S. (1982). An investigation into the determinants of customer satisfaction. Journal of Marketing Research, 19(000004), 14-27.

Closs, S. \&. (2005). The role of information connectivity in making flexible logistics programs successful. International Journal of Physical Distribution \& Logistics Management, 35(3/4), 258277.

Cronin J., \&. T. Measuring service quality: A reexamination and extension. Journal of Marketing, $1992(56), 3$. 
Crosby, L., \& LeMay, A. Empirical Determination of Shipper Requirements for Motor Carrier Services: SERVQUAL, Direct Questioning and Policy Capturing Methods. Journal of Business Logistics, 19(1), 139-153. dddddd. (n.d.).

Department, L. T. (2006, August 28). Logistics Dictionary. Retrieved from U.S. Army Quartermaster Center and School: http://www.quartermaster.army.mil/ltd/logisticsdictionary.html

Dresner, M. \&. Customer service, customer satisfaction, and corporate performance in the service sector. Journal of Business Logistics, 16(1), 23-40.

Elmadag, A. B. (2008). Antecedences and Consequences of frontline service employee committment to service quality. Journal of Marketing Theory and Practice, 16(2), 95-110.

Ghobadian, A. S. (1994). Service quality-concepts and models. International Journal of Quality \& Reliability Management, 11(9), 43-66.

Gilmour, P. D. (1994). Customer service: Differentiating by market segment. International Journal of Physical Distribution \& Logistics Management, 24(4), 18-24.

Greising, D. (1994, August 8). Quality: How to make it pay. Business Week, pp. 54-59.

Gronroos, C. (1984). A Service Quality Model and its Marketing Implications. European Journal of Marketing, 18(4).

Gummesson, E. (2008). Customer centricity: Reality or a wild goose chase? European Business Review, 10(1), 4-13.

Ha, A. L. (2003). Price and delivery logistics competition in a supply chain. Management Science, 49(9), 1139-1153.

Hartline, M. \&. (1996). The management of customer-contact service employees: An empirical investigation. Journal of Marketing, 60(4), 52-70.

Hoffman, M. (2006, June 2). logistics-dictionary.com. Retrieved February 19, 2016, from logisticsdictionary.com: logistics-dictionary.com

Hoffman, M. (2013, June 12). logistics-dictionary.com. Retrieved February 2, 2016, from logisticsdictionary.com: logistics-dictionary.com

Hopkins, S. S. (1993). Service quality gaps in the transportation industry: An empirical investigation. Journal of Business Logistics, 14(1), 145-162.

Hunt, S. D. (1983). General theories and the fundamental explanda of marketing: A formalization. Journal of Marketing, 47(4), 9-17.

Kattara, H. W. (2008). The impact of employee behavior on customers' service quality perceptions and overall satisfaction. Tourism and Hospitality Research, 8(7), 309-323.

Kirkeby, K. Employee/customer interface in a service crisis: Impact of senior management attributes and practices on customer evaluation. New York: McGraw-Hill.

Labor, U. D. (2009). Occupational Employment Projections. Washington: Bureau of Labor Statistics.

Ladhari, R. (2008). Alternative measures of service quality: A review. Managing Service Quality, 18(1), 65-86.

Lafferty, B., \& Colgate, M. (2001). Services marketing: Integrating customer focus across the firm. The Services Industry Journal, 21(1), 241-243.

Mandrodt, K. B. (1992). The evolution to service response logistics. International Journal of Physical Distribution \& Logistics Management, 22(9), 3-10.

Meixell, M. \&. (2008). A review of the transportation mode choice and carrier selection literature. International Journal of Logistics Management, 19(2), 183-211.

Mentzer, J. B. (1995). Best vs. worst practice. Marketing Management, 4(1), 45-46.

Mentzer, J. F. (2001). Logistics service quality as a segment-customized process. Journal of Marketing, 65(4), 82-104.

Muslim, A. (2008). An examination of the relationship between service quality perceptions and customer satisfaction: A SEM approach towards Malaysiam Islamic banking,. International Journal of Islamic and Middle Eastern Finance and Management, 1(3), 191-209.

Narasimhan, K. (2004). Services Marketing: Integrating Customer Focus Across the Firm. International Studies of Managment \& Organizations, 14(5).

70 Journal of Applied Business and Economics Vol. 20(4) 2018 
Parasuraman, A. Z. (1988). A conceptual model of service quality and its implications for future research. Journal of Marketing, 49(4), 41-50.

Parikh, D. (2005). Measuring retail service quality: An empirical study in a developing country. South Asian Journal of Management, 12(2), 43-57.

Porter, M. (1980). Competitive Advantage. Boston, MA: Macmillan.

Potocan, V. (2008). Business-to-business marketing: A study on the communication of logistical services in the former Yugoslavian nations. Business Review, Cambridge, 11(1).

Rhea, M., \& Shrock, D. (1987). Measuring the effectiveness of physical distribution customer service programs. Journal of Business Logistics, 8(1), 31-45.

Richardson, H. (2005). The pros and cons of 3pls. Logistics Today, 46(10), 17-18.

Rodriques, A. B. (2002). Estimation of global and national logistics expenditures. Journal of Business Logistics, 1-17.

Rogers, D. D. (1993). Ehancing service reponsiveness: The strategic potential. Logistics Information Management, 6(3), 27-32.

Rust, R. M. (2002). Getting a return on quality: Revenue expansion, cost reduction, or both? Journal of Marketing, 66(4), 7-26.

Scheepers, R. (2006). A conceptual framework for the implementation of enterprise information portals in large organizations. European Journal of Information Systems, 15(6), 635-643.

Seth, N. D. (2006). A conceptual model for quality in the supply chain. International Journal of Physical Distribution \& Logistics Management, 36(7).

Sheetal, S., \& Verma, H. (2004). Relative importance of service quality dimensions: A multisectoral study. Journal of Service Research, 4(1), 93-116.

SPSS, M. (1999). Simple and Multiple Linear Regression. In M.D. SPSS, SPSS Base 9.0 . Chicago: SPSS Inc.

Statistics. (2007). Transportation and Warehousing. Washington, DC: United States Department of Labor.

Statistics, B. Transportation and Warehousing. United States Department of Labor. Washington: NAICS 48-49.

Stock, J. (1997). Applying theories from other disciplines to logistics. International Journal of Physical Distribution \& Logistics Management, 27(9/10), 515-538.

Sweeney, J. C. (2007). Moving toward the service-dominant logic- A comment. Australasian Marketing Journal, 97-104.

Vansickle, J. (2002). Quality assurance program launched. National Hog Farmer, 47(2), 50-53.

Vargo, S. L. (2004). The four service marketing myths: Remnants of a goods-based manufacturing model. Journal of Service Research, 6(4), 324-335.

Walker, R., Johnson, L., \& Leonard, S. (2006). Re-thinking the conceptualization of customer value and service quality within the service-profit chain. Manager Service Quality, 16(1), 23-36.

Zacharia, Z. G. (2009). An analysis of supply chain collaboration and their effect on performance outcomes. Journal of Business Logistics, 30(2), 101-124.

Zeithaml, V. \&. (2003). Services marketing: Integrating customer focus across the firm. Burr Ridge, IL: McGraw-Hill.

Zeithaml, V. B. (1996). The behavioral consequences of service quality. Journal of Marketing, 60(2), 3145.

Zeithaml, V. Service Quality, Profitability, and the Economic Worth of Customers: What We Know and What We Need to Learn. Academy of Marketing Science Journal, 28(1), 67-85. 